ISSN: 2224-0616

Int. J. Agril. Res. Innov. \& Tech. 3 (1): 12-19, J une, 2013 Available online at http:// www.ijarit.webs.com

\title{
CONSTRAINTS AND OPPORTUNITIES FOR CULTIVATION OF Moringa oleifera IN THE ZIMBABWEAN SMALLHOLDER GROWERS
}

\author{
S.M. Mudyiwa1, C.T. Gadzirayi', J.F. Mupangwa'2, J. Gotosa' and T. Nyamugure1 \\ Received 28 February 2013, Revised 2 June 2013, Accepted 20 June 2013, Published online 30 June 2013
}

\begin{abstract}
The study sought to establish the constraints to Moringa agronomic practices and marketing in the smallholder farming sector of Zimbabwe. Purposive sampling selected 96 respondents across four study districts in Zimbabwe who were interviewed using an open-ended questionnaire. Eight focus group discussions disaggregated by gender were carried out to supplement primary data. Growers asserted Moringa oleifera production problems of livestock damage, theft, seed supply, inefficient cultivation practices resulting in inherent low productivity and poor marketing. The growers coped through intensive monoculture of M. oleifera, enhanced local seed supply from establishing their own seed orchards, product value addition and organized associations. Moringa can be used to promote climate change resilient agricultural systems and will be a solution to environmental problems.
\end{abstract}

Keywords: Moringa oleifera, Multipurpose Tree, Constraints, Growers

${ }^{1}$ Faculty of Agriculture and Environmental Science, Bindura University of Science Education, P. Bag 1020, Bindura, Zimbabwe

${ }^{2}$ Department of Animal Science, Faculty of Agriculture, University of Swaziland, P.O. Luyengo, Luyengo, Swaziland

*Corresponding author's email: silasmudyiwa@yahoo.com (S.M. Mudyiwa)

\section{Introduction}

Smallholder growers grow subsistence and cash crops in their rainfed, complex and resource deprived fields often combining the cultivation of the crops with scattered multipurpose trees and realising a wide range of benefits (Radovich, 2009). Moringa oleifera is one such multipurpose tree of global interest and is grown in combination with agricultural and horticultural crops by smallholder growers and this give growers a wide range of benefits (Palada and Chang, 2003; Radovich, 2009). It is a suitable tree for traditional agroforestry in the home because of its versatility (Odee et al., 2001; Palada and Chang, 2003; Nduwayezu et al., 2007).

M. oleifera has widespread use in agricultural industry and medicine. The tree benefits from mycorrhizal nitrogen-fixing association but there are no known residual nitrogen benefits for the next crop. Pod shucks and seed kernel press cake can be used as mulch and enhances soil fertility when they decompose (Prat et al., 2002). It can be used in livestock as a biocide. All parts of the Moringa tree are used in natural medicine. The tender leaves and pods contain a wealth of essential disease-preventing substances, for example, it is said to have known immune boosting ability (FAO, 1988; Ncube, 2006; Smith and Eyzaguirre, 2007). Moringa can be used as a source of oil and dye for water purification and wood fuel (Folkard and Sutherland, 1994).

In Zimbabwe, M. oleifera has the potential to be adopted as food for humans as well as a ruminant fodder. It can therefore fill in both human and animal nutrition gaps for the resource poor smallholder growers in need of food and livestock feed. The animals are usually a source of sustainable livelihoods. Livestock production in addition to crop production is a strategy employed to raise farm income and reduce the food insecurity experienced by rural households due to the decline in agricultural sector (J era and Ajayi, 2008). Considering the difficult agro-ecological conditions, which prevail in most parts of Zimbabwe where smallholder growers live, challenges encountered by the growers seem to be important in successful Moringa production.

With M. oleifera having such myriad of benefits this study sought for analysis and documentation of the 'invisible information' of its production constraints in agro-forestry management systems under the smallholder farming sector in various agro-ecological regions of Zimbabwe and highlight opportunities. This information will act as basis for supporting the small scale farming communities in their quest to secure better livelihoods. 


\section{Materials and Methods}

\section{The study area}

The study was conducted in Binga, Bindura, Mutoko and Shamva districts of Zimbabwe (Fig 1). These represent the main areas in the country where Moringa trees are grown and promoted for livelihoods improvement by World Agroforestry (ICRAF) and Environment Africa (E- Africa).
Table 1 shows the physical characteristics of the study districts.

The interview sites were chosen after liaison with project coordinators of the developmental agents and district extension staff of Agritex and Forestry Commission (FC). At least three wards were chosen in each district for the study (Table 1). In Binga district, Binga Trees Trust staff was involved in identifying study sites as it works in collaboration with Environment Africa.

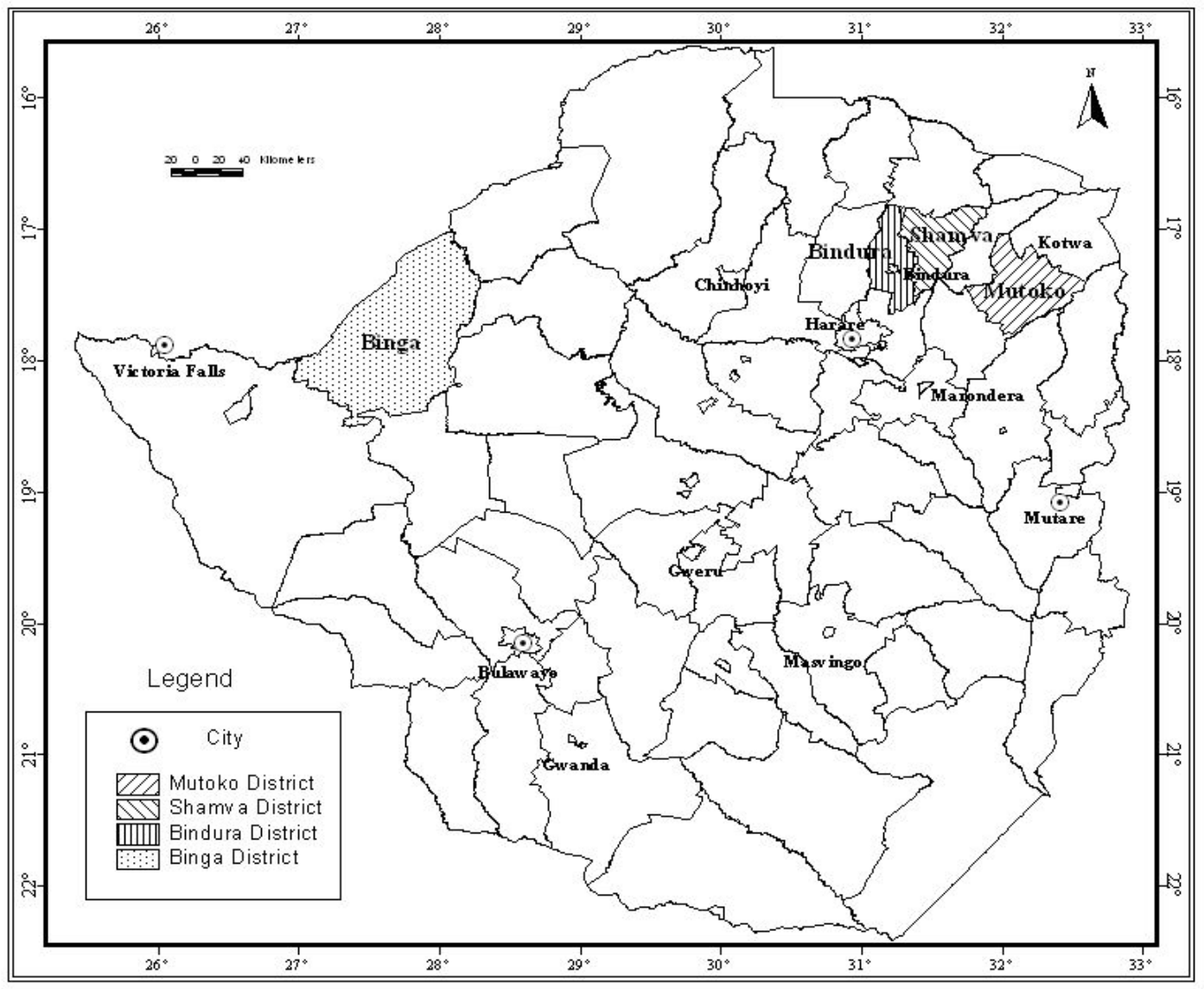

Fig. 1. Map of Zimbabwe showing location of study districts

Table 1. Physical characteristics of the study districts

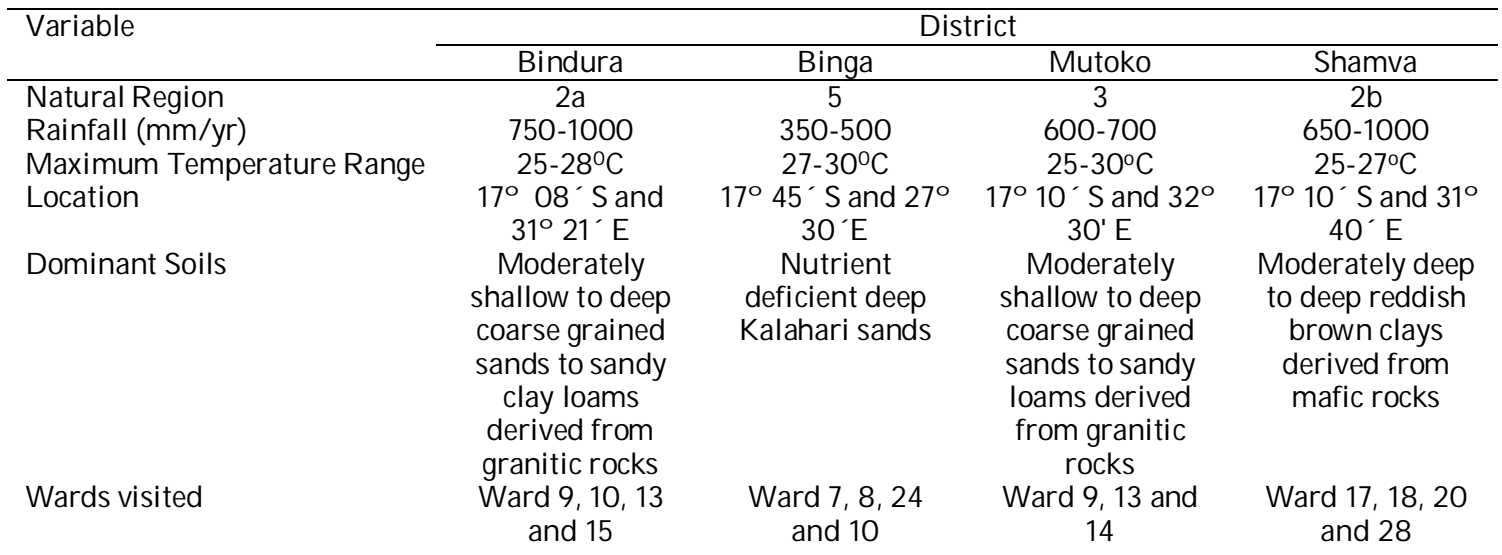




\section{Data collection}

The study employed focus group discussion, questionnaires and field observations to collect data. The snowball technique was used to identify 96 growers to be interviewed in the targeted wards. Purposive sampling was used to select participants basing on the presence of Moringa trees on their properties. Eight focus group discussions disaggregated by sex were conducted, two per district. Each focus group consisted of at least 8 members. This was to triangulate and capture gender differences. Questionnaires were administered to growers who were growing $\mathrm{M}$. oleifera trees, to capture data on challenges of Moringa production. Direct field observations were made to supplement and ground truth information collected through questionnaires and interviews.

\section{Data analysis}

Focus group discussion data were analysed qualitatively through content analysis description and this with observations complemented questionnaire primary data collected. Data from questionnaires were analysed using Statistical Analysis Systems (SAS) version 9.13 to come up with descriptive statistics of the responses to the questionnaires.

\section{Results and Discussion}

\section{Gender and age of Moringa growers}

A total of 96 growers in the four districts were interviewed. The age and gender characteristics of the growers are as shown in Table 2. The modal age of the interviewees was the 30-39 years, whilst more $(+2)$ male informants participated in the study.

Table 2. Age and gender characteristics of the Moringa growers

\begin{tabular}{lcc}
\hline Attribute & Categories & Number of respondents \\
\hline \multirow{2}{*}{ Gender } & Male & 49 \\
& Female & 47 \\
\hline \multirow{3}{*}{ Age } & $20-29$ & 19 \\
& $30-39$ & 36 \\
& $40-49$ & 24 \\
\multirow{3}{*}{ Location } & $50-59$ & 10 \\
& 60 and above & 7 \\
\hline
\end{tabular}

\section{Moringa production constraints}

\section{Lack of knowledge on efficient production practices}

Field observations revealed that Moringa was mostly grown scattered around homesteads (52\%), in association with fruit trees in family orchards (14\%) without irrigation and in home gardens (34\%) where trees were grown on the edges. Binga district had one thriving home garden where Moringa was intercropped with different horticultural crops. The trees would benefit from irrigation water while horticultural crops would also benefit from the shade and this saved on irrigation water requirements due to reduced evapotranspiration (Prat et al., 2002). Soil fertility would be replenished through addition of organic manure from leaf litter reducing the need to apply inorganic fertilizers.

The growers lack efficient production systems, which make use of improved models. They still used their indigenous cultivation practises to grow Binga, Mutoko, Mozambique, Malawi, and Tanzania provenances. The cultivation of Moringa in Zimbabwe needs to evolve to such an extent that growers can focus on commercial production of Moringa products like in other regions, for example, West Africa especially Niger and northern Nigeria where farmers have developed efficient farming systems that are adapted to their capacities and constraints. There, the growers have taken Moringa to the fields and grow it intensively as a crop for leaf and pod. They have abandoned subsistence production to venture into monoculture of Moringa at very high tree densities on small pieces of land or they do it in various agroforestry patterns that give them better yields (Gamatie, 2001; Saint Sauveur, 2001; Rajangam et al., 2002).

\section{Competition for land with other food crops}

Growers had small portions of land under Moringa production. The highest proportion (55\%) of growers had less than 5 trees per homestead under Moringa production. Binga district had the highest proportion (4\%) of growers with 20 or more trees per household. Bindura district had also the highest proportion (19\%) of farmers with less than 5 trees per homestead. 
Growers in Bindura, Mutoko and Shamva indicated that they felt a lot of social pressure deciding growing Moringa at their homesteads because many people stigmatise HIV and AIDs in Zimbabwe especially in the communal areas. Most people became interested in the tree when they were given the hope that it can reverse HIV status (Ncube, 2006) leading to the planting of one or two trees at the backyards without allocating it larger pieces of land as they do to their traditional crops. In Binga Moringa has been incorporated in their traditional system of primary health care and everyday nutrition hence a substantial number of trees per household.

Moringa's practical uses are uncommon to most parts of Zimbabwe except Binga because it is the region where the tree had been grown for a long time and naturalised in Zimbabwe (Maroyi, 2006). Furthermore, it is of concern that cultural knowledge concerning Moringa is absent in most districts leading to its small allocation of production areas and stigmatisation. With the knowledge at hand from developmental agents rural communities should demystify Moringa so that promotion can be fully made and Moringa can be widely grown and used as in India and other parts of Africa and realise its socioeconomic values.

\section{Source of seed}

Growers had difficulties in the procurement of germplasm. They sourced their planting material from Non Governmental Organizations (NGO) such as ICRAF, E- Africa, Development Aid from People to People (DAPP) and Binga Trees Trust, local growers and across Zimbabwe, Forestry Commission, and private nurseries. The highest proportion (51\%) of the growers got their planting material from NGOs. In Bindura and Binga districts, the highest proportion of growers got planting material from other local growers whilst in Shamva and Mutoko districts it was from NGOs. Private nurseries and Forestry Commission contributed very little as sources of germplasm as shown in Fig. 2.

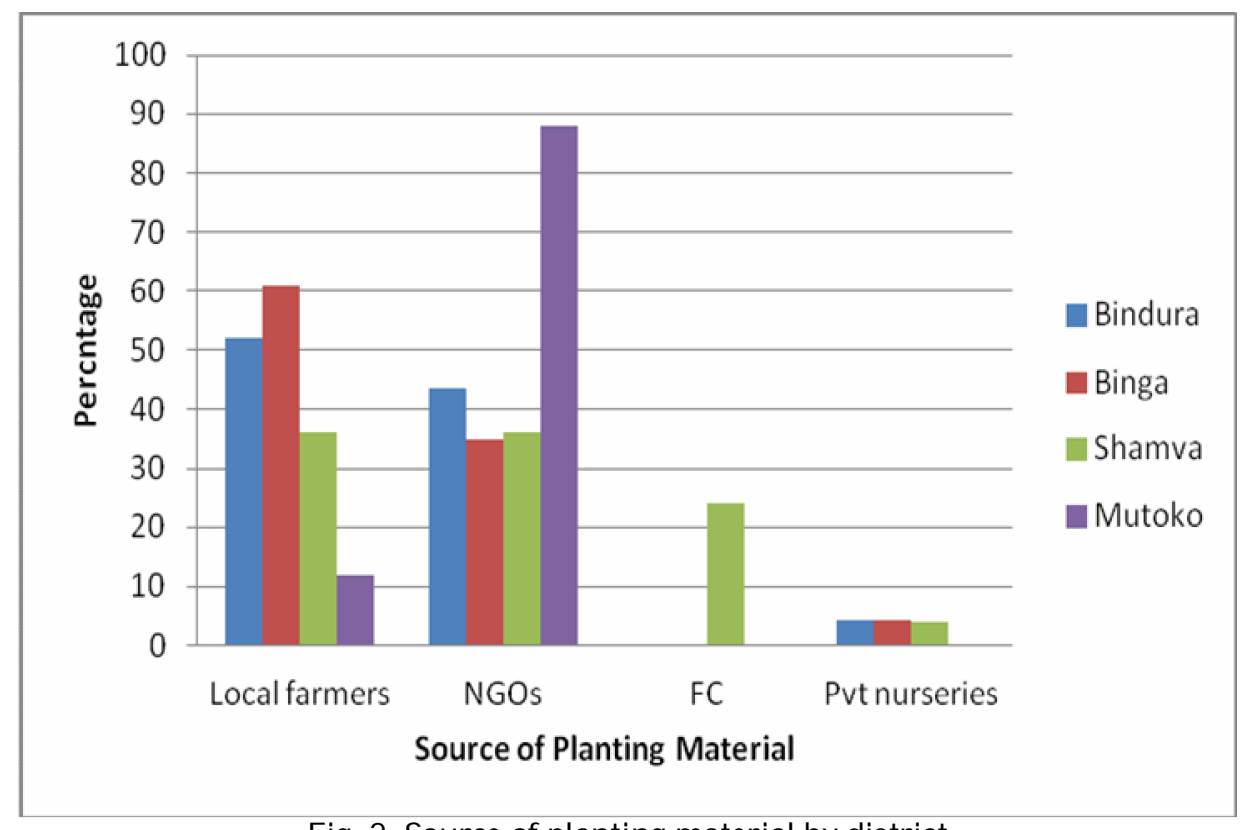

Fig. 2. Source of planting material by district

Where there is lack of information on sources of germplasm and planting material is limited, what is availed to growers is usually what they grow (Brandi et al., 2007) irrespective of the quality of the planting material. Donor agencies especially ICRAF, E- Africa (Mutoko district), Binga Trees Trust (Binga district) and DAPP (Bindura and Shamva districts) distributed the seed themselves or through Agritex and FC extension officers working with growers in the respective communities.
Growers in Binga and Bindura districts also played a major role in the supply of planting material though none of the growers was actively involved in seed production. Their trees were seldom pruned or pollarded and none of them was intentionally managed for seed production resulting in production of poor quality seed with low viabilities. Field observations have shown that most growers had no nurseries of their own or in groups except for a grower in Binga who had one which had different species of trees for her use in the family orchard shown in Plate 1 below: 


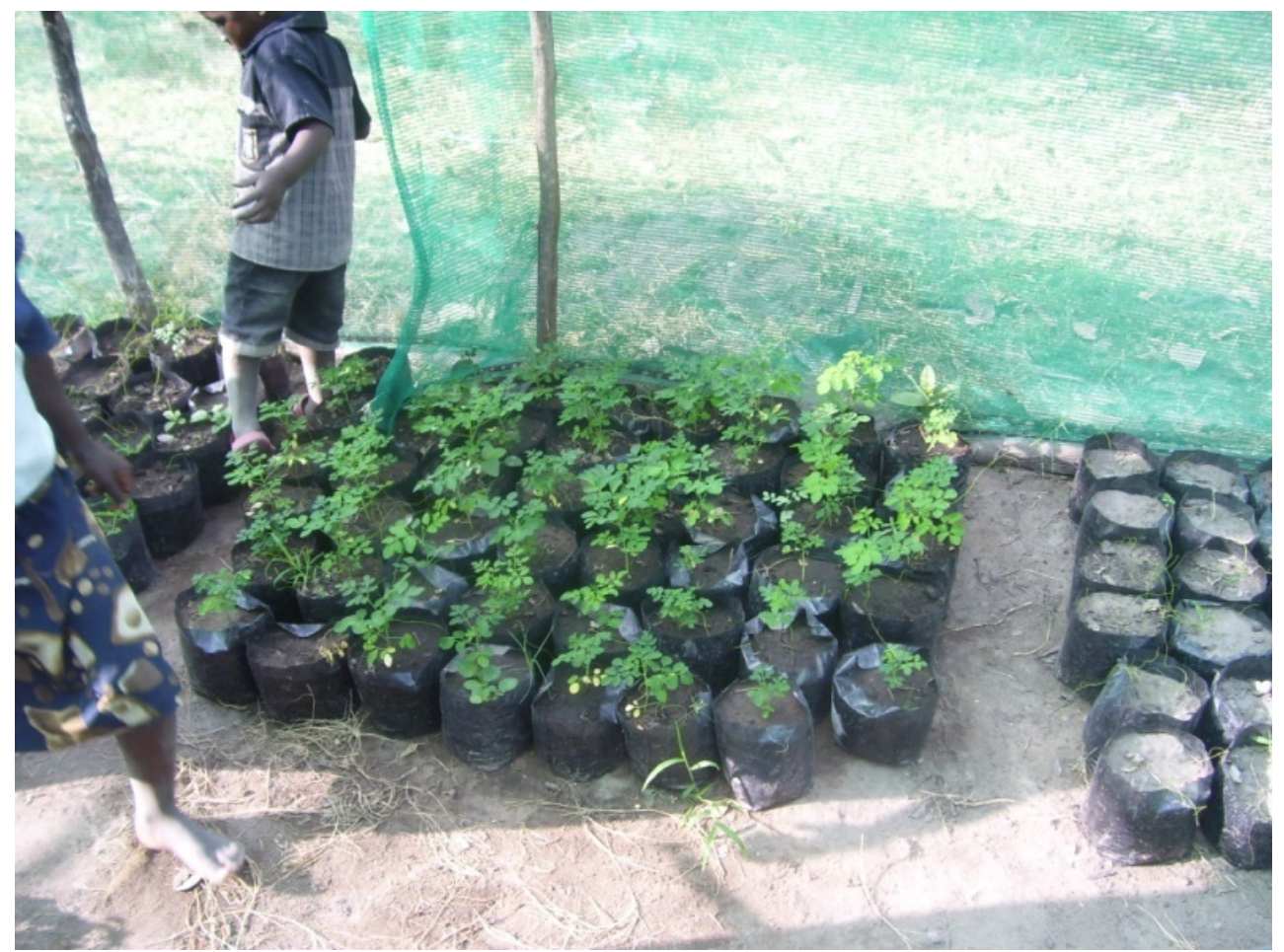

Plate 1. Grower owned nursery

Forestry Commission contributed very little as sources of planting material due to reduced mobility of its staff in offering extension services and operational constraints. This reduced their ability to carry out their institutional mandate. Little was sourced from private nurseries due to financial constraints. According to respondents, seedlings from private nurseries were expensive so growers resorted to free seed or seedlings handouts from either government or donor agencies.

\section{Shortage of water for irrigation during dry months}

Most growers (30\%) faced irrigation water shortage during dry periods. Female growers were mostly affected by problem of lack of irrigation water during dry months because they had no permanent access water points like males who are able to dig deep wells that could supply irrigation water throughout the year. In Mutoko farmers had shallow wells that dry up during the dry season or their gardens were near seasonal streams.

\section{Animal damage}

Growers (20.8\%) had problems of browsing by livestock during the dry season. The animals would destroy the trees after planting either by browsing the leaves and removing biomass or by physically trampling over the plants. Most orchards were not protected making them prone during off season when livestock is allowed to roam around looking for feed. The livestock could also break into gardens during winter season on attraction to the green Moringa foliage.

\section{Low yield levels}

The majority of the growers (70\%) had no knowledge of their yields (fresh leaf, bark and seed) from their trees. This was a result of sporadic usage of the plant parts by the growers. Moringa production is done at subsistence level so growers' fresh leaf yield levels were too low as compared to other regions though there are no specific average yields in Moringa production (Makkar and Becker, 1999; Manh et al., 2005). In Binga growers produced leaf powder due to the influence of the programme of reducing malnutrition in children (Ncube, 2006) although the production of powder was insufficient in quantity and quality and also there was no control in the preparation and storage.

\section{Theft}

Growers experienced theft of their Moringa crop. Growers in Binga revealed that thefts were rampant during periods when Moringa was viewed as a cure for HIV and AIDS prompting thieves to steal the tree parts for sell in towns to unsuspecting patients. Though thefts were experienced, there are no known well defined rural and urban markets or wholesalers in Zimbabwe for the sale of fresh leaves, pods and powder as in countries of West Africa and India. 


\section{Pests and diseases affecting the tree}

Growers experienced problems with sap sucking pests (red spider mites and aphids), caterpillars, termites and blight though a high proportion of growers encountered no pest and disease problems. Most growers in Shamva district had no problems except a few (8\%) with problems of caterpillars and in Mutoko district, caterpillars and termites were the most troublesome (Fig. 3). Bindura growers had problems with sap sucking and leaf eating pests and in Binga, red spider mite and aphids were a problem as these pests are attracted to the green foliage.

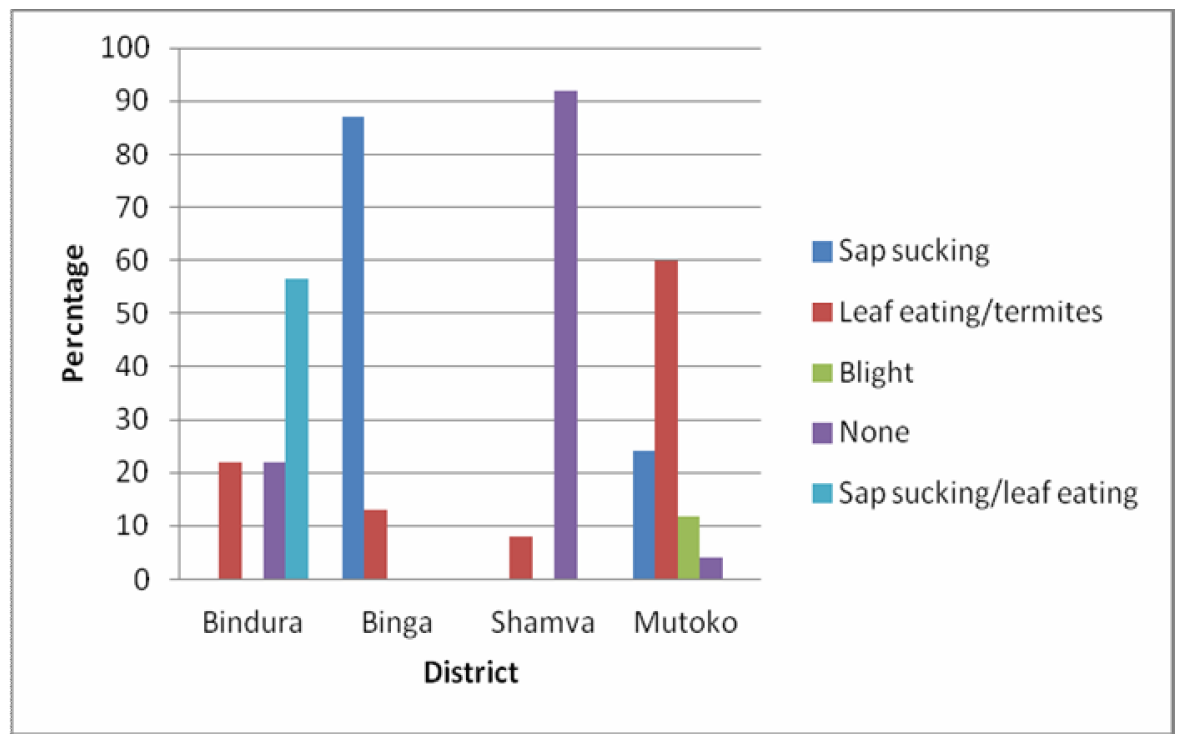

Fig.3. Pests and diseases prevalence by districts

\section{Marketing constraints}

\section{Lack of markets}

Growers have no assured markets for Moringa tree products and information regarding available markets is scarce. There is need to develop quality standards and efficient packaging and storage of Moringa products so that they meet both local and global markets if opened up. Improved marketing can also be done by creation of producer associations.

\section{Opportunities in Moringa production}

There are many opportunities that smallholder growers can grab considering the difficult agroecological conditions that prevail to secure a better livelihood from Moringa farming.

\section{Transformation of barren land}

Most smallholder growers live in marginal areas with lots of barren land near their fields or homesteads. Moringa can utilise marginal land as it is resilient to harsh growing environments, including drought and poor soil quality. Competition for land with other food crops will be reduced and land will be utilized effectively for both livestock and human food requirements enhancing food security. This will promote climate change resilient agricultural systems and will be a solution to environmental problems.

\section{Increased livelihood security and diversification}

The tree is very fast growing, with normal growth ranging from 3-5 meters per year if left uncut. Growers will quickly realize benefits from the tree in a very short period for both him and livestock. With Moringa tree parts, retaining high percentages of vital nutrients throughout the year (Melesse et al., 2012) it is an advantage for livestock production, which experiences great seasonal variations in quality and quantity of forage. Moringa, thus can be used as source of inexpensive protein to supplement poor quality forage in the dry season. This will help sustain and enhance livestock production systems and boost livelihoods.

The land reform programme that started in year 2000 has afforded some marginalized growers to bigger, more productive pieces of land which they can also use in Moringa production for both human and livestock (ruminant and non ruminant) uses. The animals are usually growers' source of sustainable livelihoods together with crop production, a strategy employed to raise farm income and reduce the food insecurity experienced by rural households due to the decline in agricultural sector (Jera and Ajayi, 2008). However, some people may fail to take up Moringa for household use or primary health care options it will still boost productivity and livelihood through improved livestock and crop 
production. Intercrops of Moringa have led to a realization of high yields in horticultural crops and its organic fertilizer has been found to be more efficient in plant growth enhancement than organic matter from other plant compost (Prat et al., 2002; Emmanuel et al., 2011) and it is a biocide.

\section{Creation of Moringa producer associations}

Women mostly participate in donor funded livelihood projects especially nutritional gardens though smaller number of men is found as members. The growers should utilize these nutritional gardens for Moringa production because the gardens have reliable water sources (boreholes) installed, security (wire fences) and management. The developmental agents teach growers better cultivation practices for better yields and post harvest management. The damages caused by livestock and humans will be minimal in the communal nutritional gardens which are cared for by the groups as each of the group members will put an eye on the project. Women also cater for the nutritional needs of the family and their acceptance of Moringa will guarantee its acceptance by the whole family.

\section{Linkage to markets and value addition}

Developmental agents are initiating, supporting and promoting projects that are aimed at value added Moringa products. The government and development agents can help open up markets and also explore export opportunities for Moringa products as growers need an assured market for their products for them to produce Moringa as a cash crop as they did for Jatropha curcas. Communication of market information should be done clearly to growers so that they can plan and implement tree growing strategies that increase productivity.

\section{Demystifying Moringa}

Cultural sensitivities in some regions should be checked as they render Moringa unacceptable to growers and Moringa tree will remain undercultivated. The belief that it is utilized by people with HIV/AIDS should be rooted out in the communities and Moringa introduced as part of daily diet. Some communities like Binga traditionally grow and use Moringa so developmental agents and extension officers can popularize Moringa with few challenges after incorporation of the different socio-cultural beliefs that may exist from one community to another. Whether moringa is used for nutritional purposes or as a medicinal health remedy, it can boost food and health security of Zimbabwe. People can use this plant regularly in part of their daily diet to fight illnesses and avoid consuming it during illness. Modern primary healthcare facilities may not be easily accessible to the communal growers and services are expensive. This can be the best option for nutritional and medicinal requirements.

\section{Water purification}

Moringa seed can also be used as a water purifier both for the urban and rural inhabitants (Ali et al., 2010). The common water purifier alum salt is an expensive option for Zimbabwe urban councils. Thus, the use of the seed can improve the availability of clean water to both rural and urban areas in a country that has a down turn of the economy since early 2000 and battling to procure enough water treatment chemicals. This will reduce exposure to waterborne diseases after using untreated water especially at household level.

\section{Conclusion}

Despite the potential of Moringa, its production has remained limited due to lack of efficient cultivation practices, livestock damage, theft, seed supply, and marketing problems. It is of no doubt that Moringa may constitute great economic and strategic value to the smallholder growers of Zimbabwe if they implement systematic tree management and marketing programmes. The current practices being used by the growers need to be altered in order to promote their production. Moringa has potential of becoming the lifeline of the small holder growers in Zimbabwe given their history of failed crops.

\section{Recommendations}

There is need to build local capacity of growers to collect and use seed. This is cheap for the growers and with time, growers can set up their own seed distribution systems with quality seed produced by them. There is need to build capacity of the growers on processing of products to add value by building appropriate technologies that suit the local requirements and situations basing on scientific knowledge to increase productivity.

\section{Acknowledgements}

The authors are greatly indebted to World Agroforestry Centre (ICRAF), Environment Africa and Binga Trees Trust for supporting this project. Many thanks go to the farmers who provided valuable information about the Moringa tree.

\section{References}

Ali, E., Muyibi, S., Salleh, H., Alam, M. and Salleh, M. 2010. Production of natural coagulant from Moringa oleifera seed for application in treatment of low turbidity water. J. Water Resource \& Protection. 2 (3): 259-266. 
Brandi, E., Lilleso, J.P.B., Moestrup, S. and Kisera, H.K. 2007. Do organizations provide quality seed to smallholders? A study on tree planting in Uganda, by NGOs and CBOs. Development and Environment No.8. Forest and Landscape, Denmark. p. 32.

Emmanuel, S.A., Emmanuel, B.S., Zaku, S.G. and Thomas, S.A. 2011. Biodiversity and agricultural productivity enhancement in Nigeria: application of processed Moringa oleifera seeds for improved organic farming Agric. Biol. J . North America. 2 (5): 867-871.

FAO. 1988. Non timber uses of selected arid zone trees and shrubs. FAO Conservation Guide 19. FAO. Rome. pp. 92-101.

Folkard, G.K. and Sutherland, J.P. 1994. Moringa oleifera: A multipurpose tree. Footsteps. 20: 14-15.

Gamatie, M. 2001. Moringa oleifera management systems in the Niger valley: The case of Sarandoarea.www.moringanews.org/actes/g amatie en.doc

Jera, R. and Ajayi, O.C. 2008. Logistic modeling of smallholder livestock farmers' adoption of tree based fodder technology in Zimbabwe. Agrekon. 47 (3): 379-392.

Makkar, H.P.S. and Becker, K. 1999. Plant toxins and detoxification methods to improve feed quality of tropical seeds. Asian-Aus. J. Anim. Sci. 12 (3): 467-480.

Manh, L.H., Dung, N.N.X. and Ngoi, T.P. 2005. Introduction and evaluation of Moringa oleifera for biomass production and as feed for goats in the Mekong Delta. Livestock Res. Rural Dev. 17 (9), Article No. 104. Retrieved May 31, 2013, from http:/ / www.lrrd.org/lrrd17/9/ manh17104.ht $\mathrm{m}$.

Maroyi, A. 2006. The utilization of Moringa oleifera in Zimbabwe, J. Sustainable Dev. 8: 172-185.

Melesse, A., Steingass, H., Boguhn, J., Schollenberger, M. and Rodehutscord, $\mathrm{M}$. 2012. Effects of elevation and season on nutrient composition of leaves and green pods of Moringa stenopetala and Moringa oleifera. Agroforestry Systems. 86: 505-518.

Ncube, D. 2006. Moringa programmes in Binga District: 10 years of experience. Binga Trees Trust. Binga. pp. 1-4.
Nduwayezu, J.B., Chamshama, S.A.O., Mugasha, A.G., Ngaga, Y.N., Khonga, E.B. and Chabo R.G. 2007. Comparison in seed kennel sizes and early growth performance of different Moringa oleifera provenances in Southeast Botswana. Discov. Innov. 19: 52-58.

Odee, D.W., Muluvi, G.M., Machua, J., Olson, M.E. and Changwony, M. 2001. Domestication of Moringa Species in Kenya, Development potential for Moringa products. Workshop proceedings October 29th - November 2nd. 2001. Dar es Salaam. Tanzania.www.moringanews.org/ actes/ ode e en.doc

Paladā, M.C. and Chang, L.C. 2003. Suggested cultural practices for Moringa. AVRDC. 545: 1-5.

Prat, J.H., Henry, E.M.T., Mbeza, H.F., Maka, E. and Satali, L.B. 2002. Malawi Agroforestry Extension Project Marketing and Enterprise Project Report. Agroforestry Publication No. 47. pp. 53-62.

Radovich, T. 2009. Farm and forestry production and marketing profile for Moringa (Moringa oleifera). In: Elevitch, C.R. (ed.) Specialty Crops for Pacific Island Agroforestry. Permanent Agriculture Resources (PAR), Holualoa, Hawaii. http:/ /agroforestry.net/ scps.

Rajangam, J., Azahakia Manavalan, R. S., Thangaraj, T., Vijayakumar, A. and Muthukrishan, N. 2002. Status of production and utilization of Moringa in southern India. Development potential for moringa product, Workshop proceedings held on 29 October- 2 November 2002. Dar es Salaam. Tanzania. http:/ / www.moringanews.org/ actes/ rajang am en.doc.

Saint Sauveur, A. 2001 Moringa exploitation in the world: State of knowledge and challenges. Dar es Salaam. Tanzania. www.moringanews.org/actes/ saintsauveur en.doc

Smith, F.I. and Eyzaguirre, P. 2007. African leafy vegetables: Their role in the world health organisation's global fruit and vegetables initiative. African J. Food Agric. Nutri. \& Dev. 7 (3): 1-17. 